\title{
Öğrenci Hemşirelerin Öğrenme Stratejileri ve Stillerinin Belirlenmesi ${ }^{1}$
}

\author{
Sevim ÇELIK ${ }^{1}$, Dilek YILDIRIM ${ }^{2}, \ddot{O} z d e m B A T U R^{3}$, Elif ÇIMME ${ }^{3}$, \\ Fatma ÇAPRAZ $Z^{3}$, Nagihan KUBAT ${ }^{2}$ \\ ${ }^{1}$ Bülent Ecevit Üniversitesi, Zonguldak Sağlık Yüksekokulu \\ ${ }^{2}$ Ögrrenci Hemşire, Bülent Ecevit Üniversitesi, Zonguldak Sağlık Yüksekokulu \\ ${ }^{3}$ Hemşire, Zonguldak Karaelmas Üniversitesi Sağllk Yüksekokulu Mezunu \\ sevimakcel@yahoo.com
}

\begin{abstract}
Özet
$\mathrm{Bu}$ araştırma, hemşirelik öğrencilerinin kullandıkları öğrenme stil ve stratejilerini belirlemek amacıyla gerçekleştirilmiştir. Bülent Ecevit Üniversitesi Sağlık Yüksek Okulu Hemşirelik Bölümü’nde okuyan 304 öğrenci ile kesitsel tipte yapılmıştır. Veriler, sosyo-demografik anket formu, Öğrenme Stilleri Envanteri ve Genel Öğrenme Stratejileri Değerlendirme Ölçeği kullanılarak toplanmıştır. Veriler SPSS 16.00 paket programında frekans, aritmetik ortalama, yüzde, tek yönlü varyans analizi, student $\mathrm{t}$ testi, ki-kare testi ve Kruskal Wallis testi ile değerlendirilmiştir. Öğrencilerin daha sıklıkla yerleştiren (\%33) ve ayrıştıran (\%29) öğrenme stiline sahip olduğu belirlenmiştir. Cinsiyetleri $\left(\chi^{2}=10.8 ; p=0.01\right)$ ve mezun oldukları okul $\left(\chi^{2}=13.2 ; \quad \mathrm{p}=0.04\right)$ ile öğrenme stilleri arasında istatistiksel anlamlı farklılık saptanmıştır. Öğrencilerin dikkat (3.86 \pm 0.49$)$, bilişi yönetme (3.67 \pm 0.63$)$, anlamlandırma (3.68 \pm 0.50$)$, zihne yerleştirme $(3.59 \pm 0.60)$, hatırlama $(3.77 \pm 0.59)$, duyuşsal $(3.47 \pm 0.50)$ ve tekrar stratejilerini (3.69 \pm 0.52$)$ "sıklıkla" kullandıkları belirlenmiştir. Öğrencilerin kaldı̆̆ yer, haftalık çalışma saati, kitap okuma alışkanlığı ve anne eğitim düzeyi ile öğrenme stratejileri arasında istatistiksel anlamlı farkl1l1k bulunmuştur $(\mathrm{p}<0.05)$. Öğrencilerin demografik özelliklerinin öğrenme stilleri ve stratejilerinde etkili olduğu saptanmıştır.
\end{abstract}

Anahtar Kelimeler: Öğrenci hemşire, öğrenme stratejileri, öğrenme stilleri

\section{Determination of Student Nurses' Learning Strategies and Styles}

\begin{abstract}
This research has been carried out in order to determine the methods and strategies of learning which have been used by the nursing students. This research has been conducted as a crosssectional research with 304 students who have attended nursing department at Bülent Ecevit University, School of Health. Data has been collected by a socio-demographic survey form and The Learning Methods Inventory, Evaluation Criterion of General Learning Strategies. Data have been evaluated by frequency, mean, percentage, one way Variance Analysis, Student t test, chisquare test and Kruskal Wallis test on the SPSS packet program. It has been determined that
\end{abstract}

\footnotetext{
${ }^{1}$ 10. Ulusal Uluslararası Katılımlı Hemşirelik Öğrencileri Kongresi, 28-30 Nisan 2011, Gaziantep’te poster bildiri olarak sunulmuştur.
} 
students have a more fitting (33\%) and decomposing (29\%) learning style. It has been determined that there are statistical significant differences between the gender $\left(\chi^{2}=10.8 ; p=0.01\right)$ and the graduated schools $\left(\chi^{2}=13.2 ; \mathrm{p}=0.04\right)$ with learning style. It has been determined that students use attention (3.86 \pm 0.49$)$, management of acquaintance interpretation (3.67 \pm 0.63 ), interpreting (3.68 \pm 0.50$)$, memorizing audio (3.77 \pm 0.59$)$, placing in mind (3.59 \pm 0.60$)$, emotional $(3.47 \pm 0.50)$ and repetition strategies $(3.69 \pm 0.52)$. It has been found that there is a statistical significant difference between students' place of residence, the habit of reading book and mother education level with learning strategies $(\mathrm{p}<0.05)$. It has determined that demographic features of students effect on the learning styles and strategies.

Keywords: Nursing student, learning styles and learning strategies.

\section{Giriş}

Bilgi çağı olarak adlandırılan bu dönemde ülkeler bilgi edinen ve bilgi üreten bir toplum oluşturmak için eğitim-öğretim sistemi içerisinde, öğrencilerin nasıl düşündükleri ve nasıl öğrendikleri ile ilgili konuları tartışmaktadır. Bilgi üreten topluma ulaşabilmek sürecinde bireylerin araştırma yapabilme, sorun çözebilme, yaratıcı düşünme, eleştirel düşünme yeteneğine sahip olabilmelerinin, eğitimleri sırasında öğrenme stil ve stratejilerinin doğrultusunda geliştirilen eğitim-öğretim politikaları ile mümkün olduğu bir gerçektir (Atay, İbiş ve Kartal 2007; Beşoluk ve Önder 2010; Tuncer ve Güven 2007).

Literatürde, öğrenme stratejisi, öğrencinin kendi kendine öğrenmesini kolaylaştıran teknikler; öğrenme stili de öğrencinin öğrenmeye yönelik eğilimlerini ya da tercihlerini yansıtan özellikler olarak tanımlanmaktadır. İçeriklerinin birbirlerinden farklı olduğu belirtilen bu kavramlardan öğrenme stillerinin, öğrenme sürecinde kullanılan bütün stratejileri kapsadığı; öğrenme stillerinin temel öğelere sahip olup değişmediği, öğrenme stratejilerinin ise istenilen bilgiye ulaşabilmek için öğrenilebilir ve zaman içinde geliştirilebilir olduğu belirtilmektedir. Diğer bir ifadeyle, öğrenme stillerinin bireyin farkında olmadan kullandığı içsel becerileri, öğrenme stratejilerinin ise öğrenenlerin isteyerek ve sık sık kullandığı dışsal becerileri tanımladığı bildirilmektedir (Cesur 2008; Güven 2008; Güven 2007; Öztürk 1995; Uzuntiryaki, Bilgin ve Geban 2004).

Öğrenme stratejileri ve stilleri, öğrenme sırasında bireyin güdülenmesi ve yeni öğrenilen davranışların kalıcı duruma gelmesinde etkili yöntemlerdir. Bu nedenle öğrencilerin nasıl düşünmeleri ve nasıl öğrenmeleri gerektiği konularına son derece önemlidir. Öğrencilerin öğrenirken kullandığı birçok öğrenme stratejisi ve stillerinin bulunmakta, kullanılan strateji ve stillerdeki farkl111kların öğrencinin bireysel tercihlerinden, geçmiş yaşantısından, zeka düzeyinden, işin algılanan güçlük derecesinden ya da yeteneğine ilişkin beklentilerinden kaynaklandığı bilinmektedir. Ayrıca, bu tekniklerin yapılan çalışmalarda, öğrencinin akademik başarısında ve mezuniyet sonrası iş yaşantısında etkili olduğu, öğrenme stratejisi ve stili ile uyum göstermeyen bir eğitim sistemi öğrenim gören kişinin güven ve başarısında olumsuz sonuçlara yol açabileceği bildirilmektedir (Cesur 2008; Öztürk 1995; Veznedaroğlu ve Özgür 2005).

Bireyin, ailenin ve toplumun sağlığını koruma, geliştirme ve hastalık halinde iyileştirmeye hizmet eden hemşirelik mesleğine sahip olacak öğrenci hemşirelerin de eğitim-öğretim sürecine etkin katılımları, araştırabilme, sorun çözebilme, yaratıcı düşünme ve eleştirel düşünebilmeleri zorunludur. Sürekli gelişen bilgi ve teknolojiye paralel olarak değişen sağlık bakım sistemi, bakım gereksinimleri ve bakım uygulamalarını gerçekleştirebilmeleri için onların öğretim stratejileri ve stilleri dikkate alınarak geliştirilen eğitim programları ile mümkündür. Yapılan çalışmalar incelendiğinde, öğrenci hemşirelerin eğitiminde öğrenme strateji ve stillerini değerlendiren çalışmaların az olduğu görülmektedir (Güven ve Kürüm 2006; Kaya ve Akçin 2002; Uçan, Taşc1 ve Ovayolu 2008). 
$\mathrm{Bu}$ kapsamda araştırma, öğrenci hemşirelerin öğrenme stratejilerini kullanma ve öğrenme stillerini belirleyerek eğitim programları ile ilgili yeni öneriler getirmektir.

\section{Araştırma Soruları}

Araştırmada, amaç doğrultusunda aşağıdaki sorulara yanıt aranmıştır:

1. Öğrenci hemşirelerin öğrenme stratejilerini kullanma durumları nedir?

2. Öğrenci hemşirelerin öğrenme stratejilerini kullanma durumları ile demografik özellikleri arasında anlamlı farklilık var midır?

3. Öğrenci hemşirelerin öğrenme stilleri nelerdir?

4. Öğrenci hemşirelerin öğrenme stilleri ile demografik özellikleri arasında anlamlı farklılık var midır?

\section{Gereç ve Yöntem}

Araştırmanın Tipi: Araştırma, tanımlayıcı ve kesitsel nitelikte bir çalışmadır..

Araştırmanın Evreni ve Örneklemi: Araştırmanın evrenini, 2010-2011 eğitim-öğretim yılında Bülent Ecevit Üniversitesi Sağlık Yüksekokulu Hemşirelik Bölümü’nde okumakta olan 396 öğrenci oluşturmuştur.

Araştırmada tüm evrene ulaşılması hedeflenmiş̧ir. Ancak 43 öğrenci araştırmanın yapıldığı tarihlerde okulda bulunmadığından, 45 öğrenci ankete katılmak istemediğinden, dört öğrenci de anketi yetersiz doldurduğundan araştırma kapsamına alınmamıştır. Bu nedenlerden dolayı araştırma 304 öğrenci ile gerçekleştirilmiştir. Araştırmaya katılım oranı \% 77 'dir.

Verilerin Toplanması: Veriler, 13-17.12.2010 tarihleri arasında öğrenci hemşirelerin demografik özelliklerini değerlendiren sosyo-demografik özellikler anketi, Öğrenme Stilleri Envanteri ve Genel Öğrenme Stratejileri Değerlendirme Ölçeği kullanılarak toplanmıştır.

Sosyo-demografik özellikler anketi: Anket formu öğrencilerin yaşı, cinsiyeti, kardeş sayısı, kaçıncı çocuk olduğu, yaşadığı yer gibi özelliklere ilişkin 12 sorudan oluşmaktadır.

Öğrenme Stilleri Envanteri: Kolb (1985) tarafindan geliştirilen envanter, 1993 yılında Akkoyunlu ve Aşkar tarafından Türkçeye çevrilerek uyarlaması yapılarak geçerlilik güvenirliği yapılmıştır (Tablo 1) (Aşkar ve Akkoyunlu 1993; Bahar, Özen ve Gülaçtı 2009).

Tablo 1. Öğrenme Stili Envanterinin Güvenirlik Katsaylları

\begin{tabular}{l|cc}
\hline \multirow{2}{*}{ Öğrenme Biçimleri } & Cronbach Alpha & \\
\cline { 2 - 3 } & $\begin{array}{c}\text { Kolb (1985) } \\
(\mathrm{n}=268)\end{array}$ & $\begin{array}{c}\text { Aşkar-Akkoyunlu(1993) } \\
(\mathrm{n}=103)\end{array}$ \\
\hline SY & .82 & .58 \\
YG & .73 & .70 \\
SK & .83 & .71 \\
AY & .78 & .65 \\
SK-SY & .88 & .77 \\
AY-YG & .81 & .76 \\
\hline
\end{tabular}


Envanterde toplam 12 soru bulunmakta, her bir soru kendi arasında dört ayrı ifadeye ayrılmış, toplam 48 alt maddeden oluşmaktadır. Öğrencilere sorulan her soruda kendisine en uygun seçeneğe 4 puan, en az uygun olana ise 1 puan verilmesi istenilmektedir. Değerlendirme sirasında her sorunun birinci alt maddesi somut yaşantı (SY), ikincisi yansıtıcı gözlem (YG), üçüncüsü soyut kavramsallaştırma yeteneği (SK) ve dördüncüsü aktif yaşantı yeteneği (AY) şeklinde ifade edilmektedir. Öğrencinin her ifadeye verdiği puan sonucunda her bir ifade için 12-48 arasında bir puan elde edilmektedir. SK'dan SY puanı çıkarılarak ve AY'den YG puanı çıkarılarak birleştirilmiş puan elde edildikten sonra (SK-SY, AY-YG) diyagramda kesişen iki nokta bireye en uygun öğrenme stilini vermektedir. SK-SY sonucu puan pozitif ise öğrenme soyut, negatif ise somut olarak tanımlanmaktadır. AY- YG sonucu puan pozitif ise aktif yaşantı, negatif ise ögrenmenin yansıtıcı olduğunu göstermektedir (Şekil 1).

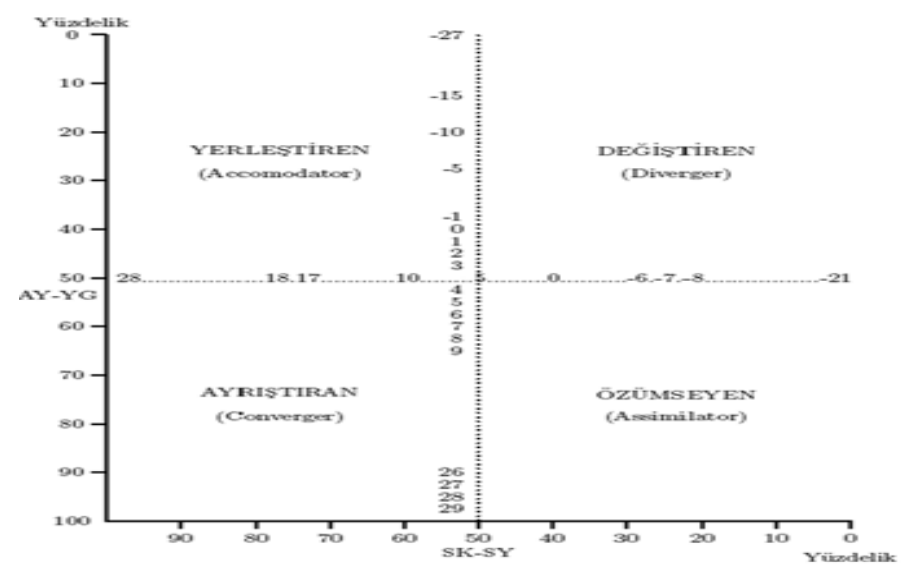

Şekil 1.Yaşantısal Öğrenme Kuramına Göre Öğrenme Stillerinin Yer Aldı̆̆ı Boyutlar

Genel Öğrenme Stratejileri Değerlendirme Ölçeği: Öztürk (1995) tarafından geliştirilen bu ölçek öğrencilerin öğrenme stratejilerini ne ölçüde kullandıklarının belirlenmesi ve bu konudaki problemlerin çözümüne yardımcı olabilmek için geliştirilmiştir. Ölçekte; dikkat, tekrar, anlamlandırma, zihne yerleştirme, hatırlama, bilişi yönetme ve duyuşsal stratejiler olmak üzere yedi strateji bulunmaktadır. 7 strateji altında 6 dikkat, 9 tekrar, 6 zihne yerleştirme, 6 hatırlatma, 6 bilişi yönetme, 11 duyuşsal olmak üzere 63 davranış maddesi yer almaktadır. Her bir davranışın öğrenci tarafından kullanım sıklığını saptamak için likert tipi bir ölçekle yanıtlar hiç, çok az, ara sıra, sıklıkla, her zaman şeklinde değerlendirilmektedir. Öğrencilerin öğrenme stratejilerini kullanma düzeyleri; 1.00-1.79 "Hiç", 1.80-2.59" Çok az", 2.60-3.39 "Ara sıra", 3.40-4.19 "Siklıkla", 4.20-5.00 "Her zaman" aralığına göre puanlanmaktadır. Ölçeğin güvenirliğinin sağlanmasında test-tekrar test yöntemi kullanılmıştır (Tablo 2) (Öztürk 1995).

Tablo 2. Genel Öğrenme Stratejileri Değerlendirme Ölçeği Güvenirlik Katsayıları

\begin{tabular}{lc}
\hline Genel Öğrenme Stratejileri & $\begin{array}{l}\text { Cronbach Alpha } \\
\text { Öztürk (1995) }\end{array}$ \\
\hline Dikkat stratejisi & .64 \\
Tekrar stratejisi & .71 \\
Anlamlandırma stratejisi & .74 \\
Zihne yerleştirme stratejisi & .61 \\
Bilişi yönetme stratejisi & .79 \\
Duyuşsal stratejisi & .64 \\
Hatırlama stratejisi & .71 \\
\hline
\end{tabular}


Verilerin Değerlendirilmesi: Veriler SPSS 13.0 programında yüzdelik, aritmetik ortalama, standart sapma, tek yönlü ANOVA, Student t testi, Kruskal Wallis testi ve ki-kare testi ile değerlendirilmiştir. Öğrencilerin öğrenme stratejilerini kullanma durumlarını belirlemek için normal dağ 11 m gösteren ve örneklemi 30 ve üzeri olan üç ve üzeri grupların karşılaştırılmasında tek yönlü ANOVA, ikili grupların karşılaştırılmasında Student $t$ testi, normal dağılım göstermeyen 30'un altı olan üç ve üzeri grupların karşılaştırılmasında Kruskal Wallis testi kullanılmıştır. Tek yönlü varyans analizinde anlamlı farklılıkların nedeni Tukey HSD testi ile değerlendirilmiştir. Öğrencilerin öğrenme stillerini belirlemek için grupların karşılaştırılmasında ki-kare testi kullanılmıştır.

Etik Yaklaşım: Araştırmaya başlamadan önce yüksekokul yönetiminden yazılı izin, öğrenci hemşirelerden araştırma hakkında açıklama yapıldıktan sonra sözel olarak bilgilendirilmiş izin alınmıştır.

\section{Bulgular}

Öğrenci hemşirelerin \% 28'inin üçüncü sınıfta okuduğu, \%79.3’ünün kız öğrenci olduğu, \%49.3'ünün düz liseden mezun olduğu görülmektedir. Öğrencilerin $\% 40.5^{\prime}$ inin üç ve üzeri kardeşe sahip olduğu ve \%42.1' inin ilk çocuk oldukları belirlenmiştir. Araştırmaya katılan öğrencilerin yaklaşık yarısının (\%47.7) yurtta yaşadığı, çoğunluğunun (\%65.1) haftalık 1-5 saat arasında ders çalıştığ 1 , kitap okuma alışkanlığına $(\% 65.5)$ ve orta düzeyde gelire sahip (\%86.5) olduğu belirlenmiştir. Anne ve babalarının eğitim düzeyleri incelendiğinde, \% 70.4' ünün annelerinin, \% 53.6' sının babalarının ilköğretim mezunu olduğu görülmüştür.

Tablo 3. Öğrenci Hemşirelerin Genel Öğrenme Stratejilerini Kullanma Durumları(n=304)

\begin{tabular}{lccc}
\hline Genel Öğrenme Stratejileri & $\bar{X} \pm$ SD & Minimum & Maximum \\
& & & \\
\hline Dikkat Stratejisi & $3.86 \pm 0.49$ & 2.00 & 5.00 \\
Tekrar Stratejisi & $3.69 \pm 0.52$ & 2.44 & 5.00 \\
Anlamlandırma Stratejisi & $3.68 \pm 0.50$ & 2.42 & 4.95 \\
Zihne Yerleştirme Stratejisi & $3.59 \pm 0.60$ & 2.00 & 5.00 \\
Hatırlama Stratejisi & $3.77 \pm 0.59$ & 2.00 & 5.00 \\
Bilişi Yönetme Stratejisi & $3.67 \pm 0.63$ & 2.17 & 5.00 \\
Duyuşsal Stratejisi & $3.47 \pm 0.50$ & 2.45 & 5.00 \\
\hline
\end{tabular}

Araştırma kapsamına alınan öğrenci hemşirelerin, öğrenme sürecinde genel öğrenme stratejilerini "sıklıkla" kullandıkları belirlenmiştir. Öğrenciler arasında dikkat stratejisini kullanma ortalamasının en yüksek oranda olduğu, bunu hatırlama stratejisinin izlediği, en az olarak da duyuşsal stratejinin tercih edildiği saptanmıştır (Tablo 3). 


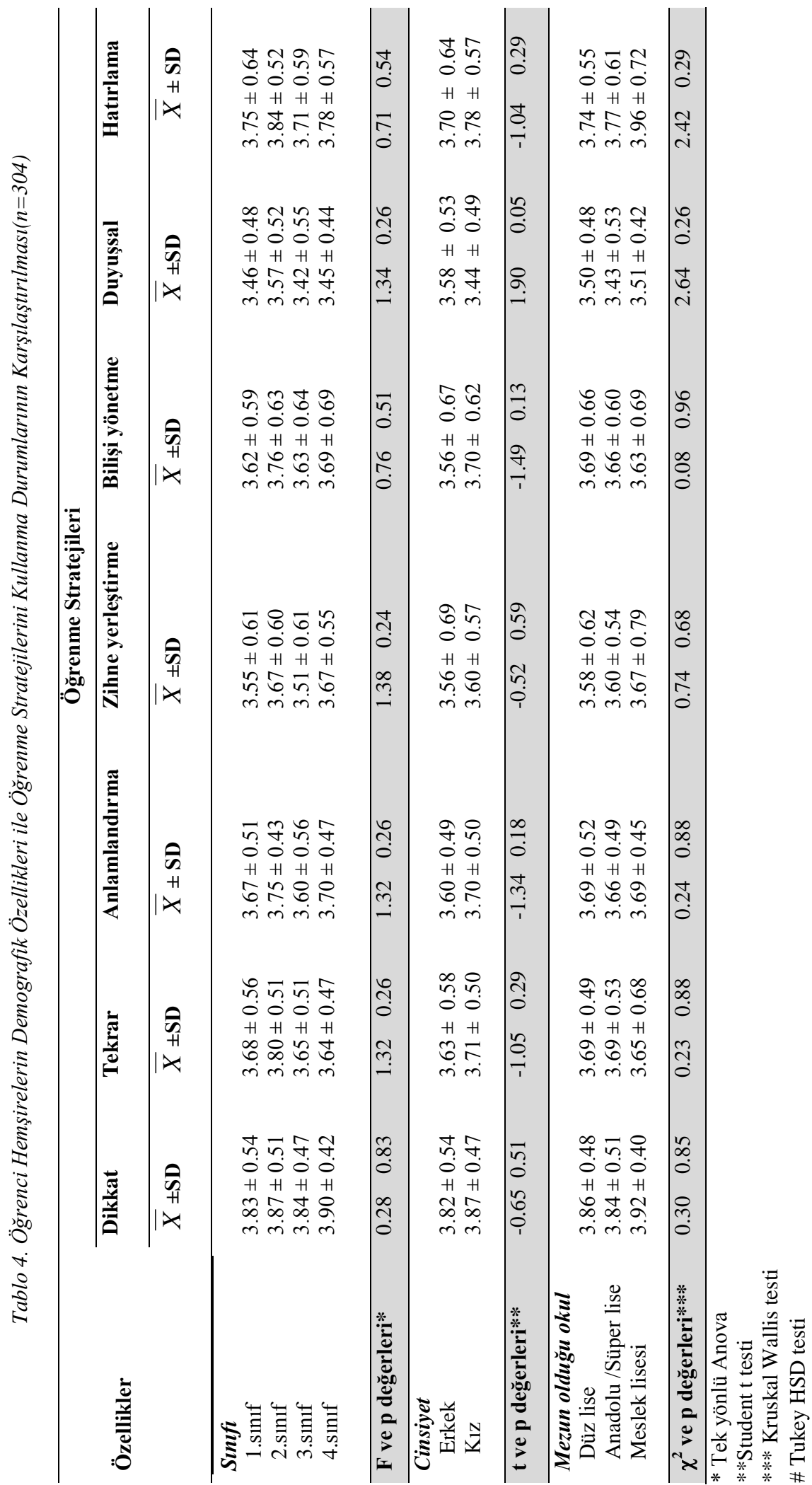




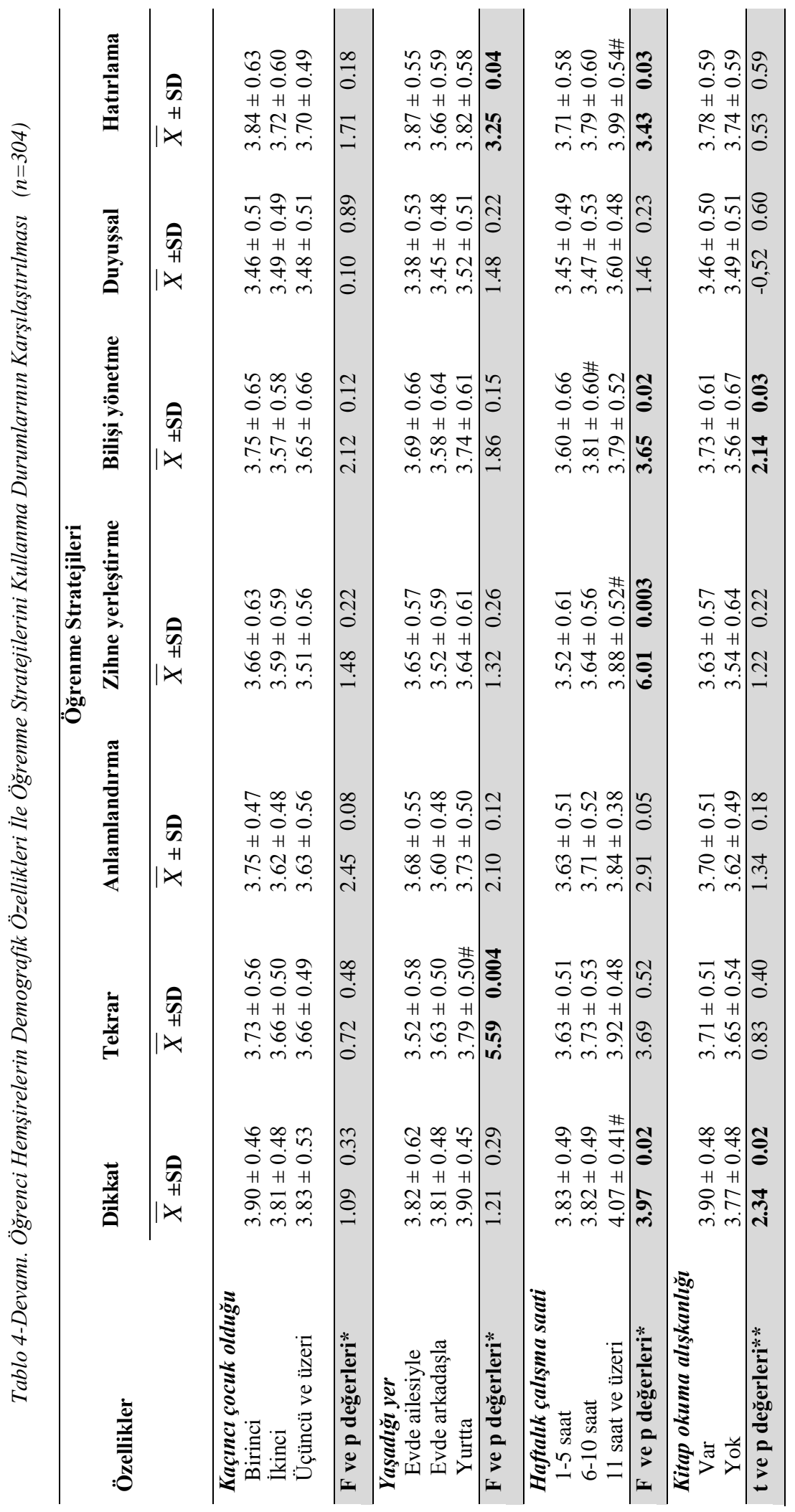




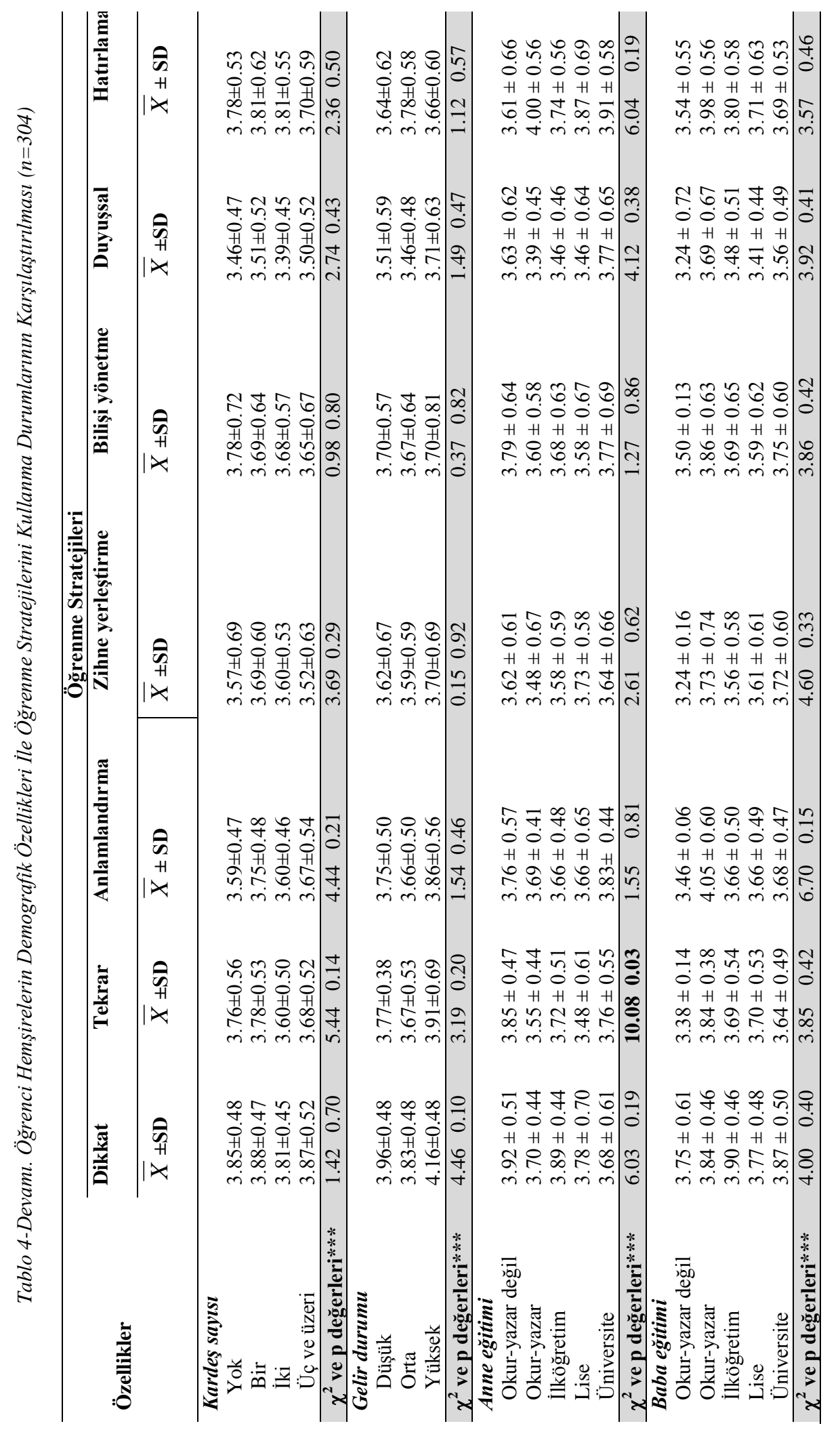


Öğrenci hemşirelerin yaşadıkları yer ile tekrar $(F=5.59 ; p=0.004)$ ve hatırlama $(F=3.25 ; p=0.04)$ stratejisini kullanma arasında istatistiksel anlamlı farklılık bulunmuştur. Tukey HSD testi ile değerlendirildiğinde, yurtta kalan öğrencilerin tekrar stratejisini kullanma sıklığının istatistiksel anlamlı farklılık gösterir şekilde daha fazla olduğu, evde ailesiyle yaşayan öğrencilerin de hatırlama stratejisini daha sıklıkla kullandıkları, ancak istatistiksel anlamlı farklılık oluşturmadığı belirlenmiştir (Tablo 4).

Öğrenci hemşirelerin haftalık çalışma saatleri ile dikkat $(\mathrm{F}=3.97 ; \mathrm{p}=0.02)$, zihne yerleştirme $(\mathrm{F}=6.01 ; \mathrm{p}=0.003)$, bilişi yönetme $(\mathrm{F}=3.65 ; \mathrm{p}=0.02)$ ve hatırlama $(\mathrm{F}=3.43 ; \mathrm{p}=0.03)$ stratejilerini kullanma arasında istatistiksel açıdan anlamlı farklılık saptanmıştır. Tukey HSD testi ile de değerlendirildiğinde, haftalık çalışma saati 11 saat ve üzerinde olan öğrencilerin istatistiksel olarak anlamlı farklılık gösterir şekilde, dikkat, zihne yerleştirme ve hatırlama stratejilerini daha sık kullandıkları, 6-10 saat ve üzerinde ders çalışanların da ise istatistiksel anlamlı derecede bilişi yönetme stratejisini daha sık kullandıkları belirlenmiştir (Tablo 4).

Tablo 4'de öğrencilerin kitap okuma alışkanlığ ile dikkat $(\mathrm{F}=2.34 ; \mathrm{p}=0.02)$ ve bilişi yönetme $(\mathrm{F}=2.14 ; \mathrm{p}=0.03)$ stratejilerini kullanma durumları arasında istatistiksel anlamlı farklılık olduğu saptanmıştır. Kitap okuyan öğrencilerin dikkat ve bilişi yönetme stratejilerini daha fazla kullandıkları belirlenmiştir.

Anne eğitimi ile öğrencilerin tekrar stratejisini kullanma durumları arasında da istatistiksel anlamlı farklılık olduğu bulunmuştur. Okuryazar olmayan anneye sahip öğrencilerin en s1k tekrar stratejisini kullandıkları belirlenmiştir (Tablo 4).

Öğrencilerin kullandıkları genel öğrenme stratejileri ile diğer demografik özellikleri arasında istatistiksel olarak anlamlı farklılık saptanmamıştır (Tablo 4).

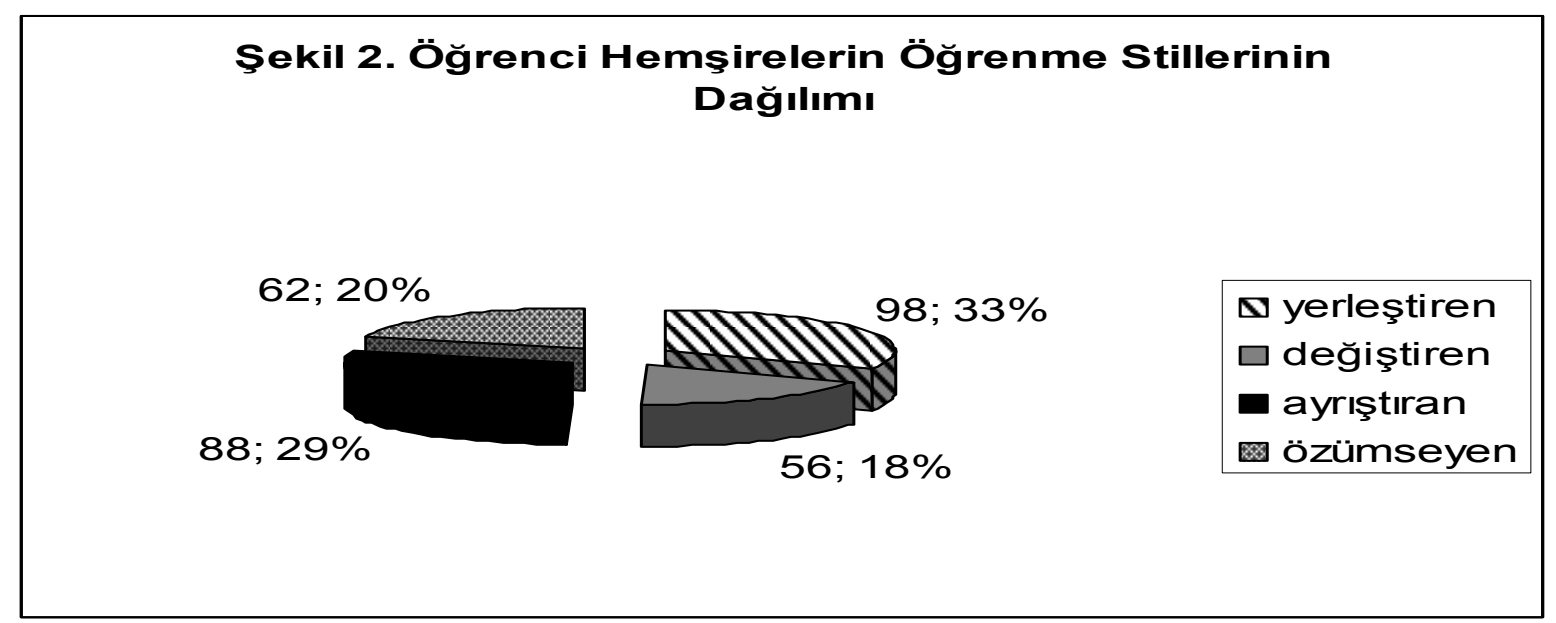

Araştırmaya katılan öğrencilerin en fazla yerleştiren ve ayrıştıran öğrenme stiline sahip olduğu saptanmıştır (Şekil 2). 
Tablo 5. Öğrenci Hemşirelerin Demografik Özellikleri ile Öğrenme Stillerinin Karşılaştırılması (n=304)

\begin{tabular}{|c|c|c|c|c|c|c|c|c|}
\hline \multirow{3}{*}{ Özellikler } & \multicolumn{6}{|c|}{ Öğrenme Stilleri } & \multirow{2}{*}{\multicolumn{2}{|c|}{ Özümseyen }} \\
\hline & \multicolumn{2}{|c|}{ Yerleştiren } & \multicolumn{2}{|c|}{ Değiştiren } & \multicolumn{2}{|c|}{ Ayrıştıran } & & \\
\hline & $\mathbf{n}$ & $\%$ & $\mathbf{n}$ & $\%$ & $\mathbf{n}$ & $\%$ & $\mathbf{n}$ & $\%$ \\
\hline Sintfi & & & & & & & & \\
\hline 1. $\sin 1 f$ & 27 & 27.6 & 15 & 26.8 & 23 & 26.1 & 18 & 29.0 \\
\hline 2. $\sin 1 f$ & 24 & 24.5 & 18 & 32.1 & 21 & 23.9 & 5 & 8.1 \\
\hline 3. $\sin 1 f$ & 26 & 26.5 & 12 & 21.4 & 25 & 28.4 & 22 & 35.5 \\
\hline 4. $\sin 1 f$ & 21 & 21.4 & 11 & 19.6 & 19 & 21.6 & 17 & 27.4 \\
\hline & \multicolumn{2}{|c|}{$\chi^{2}=11.61$} & \multicolumn{2}{|c|}{$p=0.23$} & & & & \\
\hline \multicolumn{9}{|l|}{ Cinsiyet } \\
\hline Erkek & 16 & 16.3 & 20 & 35.7 & 13 & 14.8 & 14 & 22.6 \\
\hline $\mathrm{K} 1 \mathrm{z}$ & 82 & 83.7 & 36 & 64.3 & 75 & 85.2 & 48 & 77.4 \\
\hline & \multicolumn{2}{|c|}{$\chi^{2}=10.84$} & \multicolumn{2}{|c|}{$p=0.01$} & & & & \\
\hline \multicolumn{9}{|l|}{ Mezun olduğu okul } \\
\hline Düz lise & 58 & 59.2 & 27 & 48.2 & 33 & 37.5 & 32 & 51.6 \\
\hline Anadolu/Süper lise & 34 & 34.7 & 22 & 39.3 & 50 & 56.8 & 27 & 43.5 \\
\hline Meslek lisesi & 6 & 6.1 & 7 & 12.5 & 5 & 5.7 & 3 & 4.8 \\
\hline & \multicolumn{2}{|c|}{$\chi^{2}=13.23$} & \multicolumn{2}{|c|}{$p=0.04$} & & & & \\
\hline \multicolumn{9}{|l|}{ Kaçıncı çocuk } \\
\hline Birinci & 46 & 46.9 & 15 & 26.8 & 40 & 45.5 & 27 & 43.5 \\
\hline İkinci & 25 & 25.5 & 25 & 44.6 & 24 & 27.3 & 16 & 25.8 \\
\hline \multirow[t]{2}{*}{ Üçüncü ve üzeri } & 27 & 27.6 & 16 & 28.6 & 24 & 27.3 & 19 & 30.6 \\
\hline & \multicolumn{2}{|c|}{$\chi^{2}=9.40$} & \multicolumn{2}{|c|}{$p=0.15$} & & & & \\
\hline \multicolumn{9}{|l|}{ Yaşadığı yer } \\
\hline Evde ailesi ile & 12 & 12.2 & 4 & 7.1 & 15 & 17.0 & 9 & 14.5 \\
\hline Evde arkadaşları ile & 40 & 40.8 & 22 & 39.3 & 31 & 35.2 & 26 & 41.9 \\
\hline \multirow[t]{2}{*}{ Yurtta } & 46 & 46.9 & 30 & 53.6 & 42 & 47.7 & 27 & 43.5 \\
\hline & \multicolumn{2}{|c|}{$\chi^{2}=3.87$} & \multicolumn{2}{|c|}{$p=0.69$} & & & & \\
\hline \multicolumn{9}{|c|}{ Haftalık ders çalışma saati } \\
\hline 1-5 saat & 61 & 62.2 & 33 & 58.9 & 59 & 67.0 & 45 & 72.6 \\
\hline $6-10$ saat & 23 & 23.5 & 15 & 26.8 & 17 & 19.3 & 14 & 22.6 \\
\hline \multirow[t]{2}{*}{11 saat ve üzeri } & 14 & 14.3 & 8 & 14.3 & 12 & 13.6 & 3 & 4.8 \\
\hline & \multicolumn{2}{|c|}{$\chi^{2}=5.37$} & & 0.49 & & & & \\
\hline Kitap okuma alışkan & & & & & & & & \\
\hline Var & 60 & 61.2 & 31 & 55.4 & 63 & 71.6 & 45 & 72.6 \\
\hline Yok & 38 & 38.8 & 25 & 44.6 & 25 & 28.4 & 17 & 27.4 \\
\hline & $\chi^{2}$ & & $p=$ & & & & & \\
\hline
\end{tabular}

Tablo 5 incelendiğinde, öğrenci hemşirelerin cinsiyetleri $(\chi 2=10.84 ; \mathrm{p}=0.01)$ ve mezun oldukları okul $(\chi 2=13.23 ; \mathrm{p}=0.04)$ ile öğrenme stilleri arasında istatistiksel anlamlı farkl11ı olduğu görülmektedir. Erkek öğrenciler en fazla (\%35.7) değiştiren öğrenme stilini kullanırken, kız öğrenciler ise (\%85.2) ayrıştıran öğrenme stilini kullanmaktadır. Düz lise mezunları (\%59.2) yerleştiren, Anadolu/süper lise mezunları (\%56.8) ayrıştıran, meslek lisesi mezunları (\%12.5) ise değiştiren öğrenme stilini kullanmaktadır. Öğrencilerin diğer demografik özellikleri ile öğrenme stilleri arasında istatistiksel anlamlı farklılık saptanmamıştır.

\section{Tartışma}

Araştırmada, öğrenci hemşirelerin en fazla yerleştiren ve ayrıştıran öğrenme stilini kullandıkları saptanmıştır. Bu sonuç, öğrenci hemşirelerin öğrenmede, en sık problem çözme, yeni deneyimler 
sırasında teknik analizlerin yerine insanların kişisel özelliklerine değer veren somut yaşantı ve aktif yaşantı yeteneklerini kullandıklarını göstermektedir. Daha az oranda da, problem çözme, kara verme, fikirleri pratikte uygulama, analiz yaparak akıl yürütme, sistematik plan yapma yeteneğinin kullanıldığı soyut yaşantı biçimini tercih ettikleri belirlenmiştir. Atay ve arkadaşları (2007) hemşirelik öğrencilerinde, Güllerci ve Oflaz (2010) da, sağlik ile ilgili meslek grubu olan ambulans ve acil bakım teknikerliği öğrencilerinde yaptıkları çalışmada, bu çalışmadan farklı olarak öğrencilerin özümseyen öğrenme biçimini en sık kullandıklarını bildirmişlerdir. Bu çalışmada, diğer çalışmalardan farklı olarak, öğrenci hemşirelerin somut yaşantı ve aktif yaşantı öğrenme stilini tercih etmesi bulgusu, eğitimcilerin ders planlaması sırasında soyut yaşantının yanı sıra diğer yaşantı biçimlerinin kullanımına da önem vermelerini göstermesi açısından önemlidir.

Öğrenci hemşirelerin cinsiyetlerine göre öğrenme stillerinin farklılaştı̆̆ı, erkek öğrencilerin somut yaşantı ve yansıtıcı gözlemin baskın olduğu değiştiren, kız öğrencilerin ise soyut yaşantı ve aktif yaşantının baskın olduğu ayrıştıran öğrenme stilini daha sık kullandıkları belirlenmiştir. $\mathrm{Bu}$ sonucun, iki cinsin yaradılışı gereği, toplumda kız ve erkek öğrencilere farklı sorumluluklar yükleniyor olmasından kaynaklanabileceği düşünülmektedir. Konuya ilişkin önceki çalışmaların birçoğu, öğrencilerin cinsiyetleri ile öğrenme stilleri arasında istatistiksel anlamlı farklılık bulunduğunu vurgulamışlardır. Arsal ve Özen (2007), Atay ve ark. (2007), Cesur (2008), Dinçer (2007), Eskici (2008), Karakış (2006), Mutlu (2008) ile tarafından yapılan çalışmalarda da, bu çalışma bulgusuna benzer şekilde, öğrencilerin öğrenme stillerinin kız öğrencilerin lehine değiştiği bildirilmiştir. Arslan ve Babadoğan (2005), Arsal ve Özen (2006), Fer (2003), Jones, Reichard ve Mokhtari. (2003), Kabadayı (2004), Sünbül ve Sarı (2005), Uzuntiryaki, Bilgin ve Geban (2004) bu sonucu desteklememektedir.

Öğrenci hemşirelerin okudukları sınıflar ile öğrenme stilleri karşılaştıııldığında, istatistiksel anlamlı farklılık görülmemesine karşın, birinci sınıftaki öğrencilerin yerleştiren, ikinci sınıftakilerin değiştiren, üçüncü sınıfın ayrıştıran, dördüncü sınıfın ise özümseyen öğrenme stilini kullandıkları belirlenmiştir. Bu sonuç, öğrenci hemşirelerin son sınıflarda somut yaşantı öğrenme stilinden soyut öğrenme stilini tercih etmeye doğru yönelimlerinin olduğunu göstermektedir. Bu farklılık, öğrencilerin üst sınıflarda teorik ve uygulamaları derslerin daha yoğun olduğu haftalık ders programına geçmelerinden; ayrıca, ikinci sınıf itibariyle, kişisel proje, olgu sunumları, laboratuvar çalışmaları ve bilimsel araştırma yapma çalışmalarından kaynaklanabileceği düşünülmektedir. Hemşirelik mesleği de eleştirel düşünebilme, iyi sentez yapma, çoklu bakış açısı üretebilme, yaratıcı olma, bilgisini analiz edip düzenleme, iyi bir lider olma gibi özelliklere sahip olmayı gerektirdiğinden son sinıflarda öğrencilerin bu özellikleri yansıtan ayrıştıran ve özümseyen öğrenme stillerini kullanmaları sevindiricidir. Konu hakkındaki önceki çalışmalarda da sağlık yüksekokulu öğrencilerinin okuduğu sınıflar ile öğrenme stilleri arasında istatistiksel anlamlı farklılık saptanmamıştır (Kaya ve Akcin, 2002; Uçan, Taşcı ve Ovayolu, 2008).

Güncel araştırmada, öğrencilerin mezun oldukları lise ile öğrenme stilleri arasında anlamlı bir farkın ortaya çıktığı belirlenmiş olup, düz lise, anadolu/ süper lise ya da meslek lisesi mezunu olmalarının öğrenme stillerini belirlemede etkili olabileceği dikkati çekmiştir. Araştırmada düz lise mezunlarının yerleştiren, anadolu lisesi mezunlarının ayrıştıran ve meslek lisesi mezunlarının ise değiştiren öğrenme stilini tercih ettikleri görülmüştür. Dinçer (2007) de anadolu lisesi öğrencilerinde yaptığ çalışmada, öğrencilerin en sık ayrıştıran öğrenme stilini kullandıklarını bildirmiştir. Demir (2008) tarafından yapılan farklı bir çalışmada da, mezun olunan okula göre öğrenme stilinin anlamlı şekilde farklılaştı̆̆ 1 belirtilmiş, anadolu lisesi mezunlarının ayrıştıran, meslek lisesi mezunlarının değiştiren ve özümseyen öğrenme stilini daha sık kullandıkları ifade edilmiştir. Bu sonuç, öğrencilerin okudukları liselerde öğrenme stillerinin de şekillendiğini göstermektedir. Konuya ilişkin diğer çalışmalarda, bu araştırma bulgusuna ters şekilde, öğrencilerin mezun oldukları okul ile öğrenme stilleri arasında istatistiksel anlamlı farklılık bulunmadığı bildirilmiştir (Numanoğlu 2007;Özbek 2003; Özen 2011). 
Öğrencilerin kaçıncı çocuk olduğu, yaşadığı yer, haftalık çalışma saati ile öğrenme stilleri arasında da istatistiksel anlamlı farklılık saptanmadığı gözlenmiştir. Elde edilen bu bulgular önceki araştırma bulguları ile paralellik göstermektedir (Güllerci ve Oflaz 2010).

Araştırma kapsamına alınan öğrenci hemşirelerin, öğrenme sürecinde genel öğrenme stratejilerini "sıklıkla" kullandıkları, bu süreçte en sık dikkat stratejisini, en az olarak da duyuşsal stratejiyi tercih ettikleri saptanmıştır. Sağlık yüksekokulu öğrencilerinde konuya ilişkin yapılan bir çalışmaya ulaşılamamıştır. $\mathrm{Bu}$ araştırma bulgusunu destekler şekilde, Karakış (2006), üniversite öğrencilerinin genel öğrenme stratejilerini sıklıkla kullandıklarını, en sık dikkat stratejisine, en az olarak da duyuşsal stratejiye başvurduklarını bildirmiştir. Benzer şekilde Çağlayan, Şirin ve Yıldız (2008), beden eğitimi ve spor yüksekokulu öğrencilerinin öğrenmede en az duyuşsal stratejiyi kullandıklarını ifade etmişlerdir. Güllerci ve Oflaz (2010) da farklı olarak, ambulans ve acil bakım teknikerliği bölümü öğrencilerinin en fazla duyuşsal stratejisini, en az sıklıkta da dikkat stratejisini kullandıkları belirtmişlerdir.

Araştırmada, öğrenci hemşirelerin öğrenme sürecinde kullandıkları öğrenme stratejileri ile yaşadıkları yer arasında istatistiksel anlamlı farklılık saptanmıştır. Elde edilen bulgulara göre yurtta yaşayanlar tekrar stratejisini kullanırken, evde ailesiyle beraber kalan öğrenciler hatırlama stratejisini kullanmaktadır. Yurt ortamında yaşayan öğrencilerin tekrar stratejilerini kullanmalarında ortam şartlarının etkili olduğu düşünülmektedir. Dış etkenlerin etkisi göz önüne alındığında, tekrar stratejisini sık kullanan öğrenciler, konuyu sesli olarak tekrarlama, yazılı metnin tümünü veya önemli cümleleri aynen yazma veya not alma ve altını çizme gibi yöntemleri kullanırlar. Bu güncel araştırma bulgusu Ural (2006)' in araştırması ile benzerlik gösterirken, Güllerci ve Oflaz (2010), araştırma sonucu ile ters düşmektedir.

Araştırmada elde edilen bulgulara göre, öğrencilerin haftalık ders çalışma saatleriyle dikkat, zihne yerleştirme, bilişi yönetme ve hatırlama stratejilerini kullanma düzeyleri arasında anlamlı bir farklılık görülmüştür. Bu sonucun önceki araştırma bulgularına paralel olduğu görülmektedir (Gürşimşek 2002; Yildizlar 2011).

Araştırmadan elde edilen bulgulara göre, kitap okuma alışkanlıkları ile öğrenme stratejilerinin belirlenmesi arasında anlamlı bir farklılık bulunmuş, çok sık kitap okuduğunu belirten öğrencilerin dikkat ve bilişi yönetme stratejilerini kullanma sıklığının daha yüksek olduğu saptanmıştır. Bu durum, öğrencilerin bilginin nasıl işlendiğini ve hangi konulara yoğunlaşmaları gerektiğini bildiklerini göstermektedir. Güllerci ve Oflaz (2010) da çalışmalarında, benzer şekilde kitap okuma alışkanlığı ile öğrenme stratejilerini belirleme arasında istatistiksel anlamlı farklılık olduğunu belirtmişlerdir.

Ailede eğitim, çocuğun eğitim yaşantısının temeli ve başlangıcıdır. Çocuğun ailede kazanacağı ilk eğitim yaşantıları onu okulda, meslek hayatında, toplumsal yaşantısında etkilemeye devam etmektedir. Bununla beraber ailelerin çocuğa karşı tutumu ile okul başarısı arasındaki ilişkiyi etkileyen bir faktör de onların çocukların evlerindeki çalışmalarıyla ilgilenmeleri, ödevleri hakkında yardımları ve çocuğun dersle ilgili sorduğu soruları cevaplamalarıdır. Türk toplumu olarak ataerkil bir toplum yaşantısına sahip olduğumuzdan çocukla ilgilenen kişi konumunda anne bulunmaktadır. Bu nedenle ailenin özellikle annenin eğitim düzeyi çocuğun öğrenme stratejilerini belirlemede etkilidir. Araştırmada, anne eğitimi ile çocukların öğrenme stratejilerinin belirlenmesi arasında istatistiksel anlamlı farklılık bulunmuştur. $\mathrm{Bu}$ sonuç Bengiç (2008) ve Ural (2006) tarafindan yapılan araştırmalarla da paralellik göstermektedir. Benzer şekilde Öztürk (1995)'ün çalışmasında, anne ve baba rehberliğinin öğrencilerin öğrenme stratejilerini kullanmalarında istatistiksel anlamlı farklılık oluşturduğunu bildirilmiştir. 
Diğer demografik özellikler ile öğrencilerin genel öğrenme stratejilerini kullanma durumları arasında istatistiksel anlamlı farklılık saptanmamıştır. Çağlayan ve ark. (2008) da öğrencilerin okudukları sınıf ve mezun oldukları okul arasında istatistiksel anlamlı farklılık saptamamışlardır. Karakış (2006) ise öğrencilerin cinsiyetleri ile öğrenme stratejileri arasında istatistiksel anlamlı farklılık olduğunu bildirmiştir. Güllerci ve Oflaz (2010) da öğrencilerin okudukları sınıflar ile öğrenme stratejileri arasında anlamlı fark olduğunu; kardeş sayısı, baba eğitimi arasında ise anlamlı farklılık oluşmadığını belirtmişlerdir.

\section{Sonuç ve Öneriler}

Elde edilen bulgulara göre; hemşirelik öğrencilerinin en fazla yerleştiren ve ayrıştıran, en az ise değiştiren öğrenme stiline sahip olduğu, öğrencilerin öğrenme stillerinin cinsiyete ve mezun olunan okula göre istatistiksel anlaml farklılık gösterir şekilde değiştiği, öğrenci hemşirelerin öğrenmede en fazla dikkat ve hatırlama stratejisine başvurdukları, en az olarak da duyuşsal stratejiyi tercih ettikleri, öğrencilerin tercih ettikleri genel öğrenme stratejilerinde yaşadıkları yerin, haftalık çalışma saatlerinin, anne eğitiminin, kitap okuma alışkanlığının istatistiksel anlamlı farklılık gösterir şekilde etkilediği sonucuna varılmıştır.

Bu sonuçlara göre;

Bu çalışma Zonguldak Karaelmas Üniversitesi Sağlık Yüksek Okulu Hemşirelik Bölümü'nde öğrenim gören birinci, ikinci, üçüncü ve dördüncü sınıf öğrencileriyle yürütülmüştür. Çalışmanın bulguları genellenirken, örneklemin bu özelliği dikkate alınmalı ve bu gruba göre genelleme yapılmalı, akademisyenlere ve hemşirelik öğrencilerine öğrenme stil ve stratejilerini öğretilmeli ve bilinçlenmeleri sağlanmalıdır.

\section{Kaynaklar}

Arsal, Z., Özen, R. 2007. Sınıf Öğretmeni Adaylarının Öğrenme Stratejileri ve Öğrenme Biçimi Tercihlerinin İncelenmesi. Abant izzet Baysal Üniversitesi Eğitim Fakültesi Dergisi, 7(2): 151-164.

Arslan, B., Babadoğan, C. 2005. İlköğretim 7. ve 8. Sınıf Öğrencilerinin Öğrenme Stillerinin Akademik Başarı Düzeyi, Cinsiyet ve Yaş ile ilişkisi. Eurasian Journal of Educational Research, 21: 35 - 48.

Aşkar, P., Akkoyunlu, B. 1993. Kolb Öğrenme Stili Envanteri. Eğitim ve Bilim, 87: 37-47.

Atay, S., İbiş, T., Kartal, F. 2007. Çanakkale Onsekiz Mart Üniversitesi Sağlık Yüksekokulu Öğrencilerinin Öğrenme Stillerinin Değerlendirilmesi. I. Ĕgitim Araştırmaları Kongresi, 1-3 Mayıs 2009, Çanakkale.

Bahar, H., Özen, Y., Gülaçtı, F. 2009. Eğitim Fakültesi Öğrencilerinin Cinsiyet ve Branşa Göre Akademik Başarı Durumları ile Öğrenme Stillerinin İncelenmesi. Ankara Üniversitesi Eğitim Bilimleri Fakültesi Dergisi, 42 (1): 69-86.

Bengiç, G. 2008. İlköğretim 6. ve 7. Sinıf Öğrencilerinin Öğrenme Stilleri ile Sosyal bilgiler Dersindeki Başarıları Arasındaki İlişki. Yayınlanmamış Yükseklisans Tezi, Pamukkale Üniversitesi, Denizli.

Beşoluk, Ş., Önder, İ. 2010. Öğretmen Adaylarının Öğrenme Yaklaşımları, Öğrenme Stilleri Ve Eleştirel Düşünme Eğilimlerinin İncelenmesi. Elementary Education Online, 9(2): 679-693.

Cesur, M. O. 2008. Üniversite Hazırlık Sınıfı Öğrencilerinin Yabancı Dil Öğrenme Stratejileri, Öğrenme Stili Tercihi ve Yabancı Dil Akademik Başarısı Arasındaki Açıklayıcı ve Yordayıcı İlişskiler Örüntüsü. Yayınlanmamış Doktora Tezi, Yıldız Teknik Üniversitesi, İstanbul.

Çağlayan H.S., Şirin E. F., Yıldız Ö. 2008. Beden Eğitimi ve Spor Yüksekokulu Öğrencilerinin Genel Öğrenme Stratejilerini Kullanma Düzeylerinin Bazı Değişkenlere Göre İncelenmesi. TSA, 12(2), 45-62. 
Demir, T. 2008. Türkçe Eğitimi Bölümü Öğrencilerinin Öğrenme Stilleri Ve Bunların Çeşitli Değiş̧kenlerle İlişkisi (Gazi Üniversitesi örneği). Uluslararası Sosyal Araştırmalar Dergisi, 1(4): 129-148.

Dinçer, T. 2007. Anadolu Lisesi Öğrencilerinin Öğrenme Stilleri Ve Fizik Öğrenme Stilleri. Yayınlanmamış Yükseklisans Tezi, Marmara Üniversitesi, İstanbul.

Eskici, M. 2008. Öğrencilerin Öğrenme Stilleri ile Akademik Başarıları ve Cinsiyetleri Arasındaki İlişki. Yayınlanmamış Yüksek Lisans Tezi, Trakya Üniversitesi Sosyal Bilimler Enstitüsü, Edirne.

Fer, S. 2003. Matematik, Fizik ve Kimya Öğretmenliği Öğrencilerinin Öğrenme Biçimlerine Göre Kolay Öğrendikleri Öğrenme Etkinlikleri. Çağdaş Eğitim, 304: 33-43.

Güllerci, H., Oflaz, F. 2010. Ambulans ve Acil Bakım Teknikerliği Eğitimi Alan Öğrencilerin Öğrenme Stil Ve Stratejilerinin İncelenmesi. Gülhane Tip Dergisi, 52: 112-120.

Gürşimşek, I. 2002. Öğretmen Adaylarında Öğrenmeye İlişkin Motivasyonel İnançlar ve Stratejileri Kullanımı. Muğla Üniversitesi SBE Dergisi, 8, 135-157

Güven, B. 2008. İlköğretim Öğrencilerinin Öğrenme Stilleri, Tutumları ve Akademik Başarıları Arasındaki İlişkinin İncelenmesi. TSA, 1(1).

Güven, B. 2007. Öğretimde Bireysel Farklılıklara Bakış: Bilişsel Stiller. Yeditepe Üniversitesi Eğitim Fakültesi Dergisi, 2(2), 2-3.

Güven, M., Kürüm, D. 2006. Öğrenme Stilleri Ve Eleştirel Düşünme Arasındaki İlişkiye Genel Bir Bakış. Journal of Social Sciences. 6 (1): 75-89

Jones, C., Reichard C., Kouider, M. 2003. Are Students' Learning Styles Discipline Specific? Community College Journal of Research And Practice, 27: 363-375

Kabadayı, A. 2004. İlköğretim Öğrencilerinin Bilişsel Öğrenme Stilleri ve Cinsiyetlerine Göre Karşılaştırılması (Konya İli Örneği). Ondokuz Mayıs Üniversitesi Ĕgitim Fakültesi Dergisi, 18: 1-16.

Karakış, Ö. 2006. Bazı Yükseköğrenim Kurumlarında Farklı Öğrenme Stillerine Sahip Olan Öğrencilerin Genel Öğrenme Stratejilerini Kullanma Düzeyleri. Yayınlanmamış Yüksek Lisans Tezi. Abant İzzet Baysal Üniversitesi, Sosyal Bilimler Enstitüsü, Eğitim Programları ve Denetimi Anabilim Dalı, Bolu.

Kaya, H., Akçin, E. 2002. Öğrenme Biçimleri/Stilleri ve Hemşirelik Eğitimi. C.U. Hemşirelik Yüksekokulu Dergisi, 6 (2): 31-35.

Mutlu, M. 2008. Eğitim Fakültesi Öğrencilerinin Öğrenme Stilleri. Atatürk Üniversitesi Kâzım Karabekir Eğitim Fakültesi Dergisi, 17:1-21.

Numanoğlu, Ş., Şen, B. 2007. Bilgisayar Ve Öğretim Teknolojileri Eğitimi Bölümü Öğrencilerinin Öğrenme Stilleri. Ahi Evren Üniversitesi Kırşehir Eğitim Fakültesi Dergisi Cilt 8(2): 129-148.

Özbek, Ö. 2006. Öğrenme Stillerine Uygun Olarak Düzenlenen Öğretim Etkinliklerinin Akademik Başarı, Hatırda Tutma Düzeyi ve Tutumlara Etkisi, Yayınlanmamış Yüksek Lisans Tezi, Çanakkale On Sekiz Mart Üniversitesi, Sosyal Bilimler Enstitüsü, Sınıf Öğretmenliği A.B.D. Çanakkale.

Özen, Y. 2011. Sosyal Bilgiler Eğitimi Öğretmenliği Öğrencilerinin Öğrenme Stilleri Ve Bunların Çeşitli Değişkenlerle İlişkisi. (Erzincan Üniversitesi Örneği). Akademik Bakış Dergisi, 24:1-20.

Öztürk, B. 1995. Genel Öğrenme Stratejilerinin Öğrenciler Tarafindan Kullanılma Durumları, Yayınlanmamış Doktora tezi, Gazi Üniversitesi, Sosyal Bilimler Enstitüsü, Ankara. 
Sünbül, A. M., Sarı H. 2004. An Analysis of High School Students' LearningStrategies and Styles In Turkey. International Conference on Quality In Education In The Balkan Countries, 25 th - Saturday 26th June, Sofia - Bulgaria, 1: 530-545.

Tuncer, B. K., Güven, B. 2007. Stratejileri Kullanımının Öğrencilerin Akademik Başarıları, Hatırda Tutma Düzeyleri ve Derse İlişkin Tutumları Üzerine Etkisi. Yüzüncü Yıl Üniversitesi, Eğitim Fakültesi Dergisi, 4(2): $1-20$.

Uçan, Ö., Taşçı, S., Ovayolu, N. 2008 . Eleştirel Düşünme Ve Hemşirelik. Firat Sağlık Hizmetleri Dergisi, $3(7): 17-27$.

Ural, M. 2006. Ortaöğretim Öğrencilerinin Öğrenme Ve Ders Çalışma Stratejileri ( Nevşehir İli Örneği). Eğitim Bilimleri Anabilim Dalı Eğitim Programları Ve Öğretim Bilim Dalı Yüksek Lisans Tezi, Erciyes Üniversitesi Sosyal Bilimler Enstitüsü, Kayseri.

Uzuntiryaki, E., Bilgin, İ., Geban, Ö. 2004. İlköğretim Düzeyi Öğretmen Adaylarının Öğrenme Stilleri Tercihleri ile Cinsiyetleri Arasındaki İlişkinin İncelenmesi, Hacettepe Üniversitesi Eğitim Fakültesi Dergisi, 26: 182187.

Veznedaroğlu, R.L., Özgür, A.O. 2005. Öğrenme stilleri: tanımlamalar, modeller ve işlevleri. İlköğretim Online, 4(2): $1-16$.

Yıldızlar, M. 2011. Öğretmen Adaylarının Düşünme Stillerinin Bazı Demografik Değişkenler Açısından Karşılanması. International Online Journal of Educational Sciences, 3 (1): 294-320. 
